Sports Training

\title{
Funding and performance of amateur and youth organizations in Brazil: a longitudinal analysis of a basketball league
}

\author{
Thiago José Leonardi ${ }^{1}$ (D), Diego Monteiro Gutierrez ${ }^{2}$ (D), Ariane Caroline Sarti ${ }^{2}$ (D), \\ Lucas Arromba de Souza $^{2}$ (D), Paula Simarelli Nicolau ${ }^{2}$ (D), Larissa Rafaela Galatti ${ }^{3}$ (D), \\ Roberto Rodrigues Paes ${ }^{2}$ \\ ${ }^{1}$ Universidade Federal do Rio Grande do Sul, Escola de Educação Física, Fisioterapia e Dança, \\ Porto Alegre, RS, Brasil; ${ }^{2}$ Universidade Estadual de Campinas, Faculdade de Educação Física, \\ Campinas, SP, Brasil; ${ }^{3}$ Universidade Estadual de Campinas, Faculdade de Ciências Aplicadas, \\ Limeira, SP, Brasil.
}

Associate Editor: Ricardo Augusto Barbieri, Assistant Professor at the Estácio UniSEB, Ribeirão Preto, SP, Brasil.

\begin{abstract}
Aim: The general aim was to analyze the profile of the teams participating in a basketball regional competition over 8 years (2012-2019). Specifically, we aimed to a) analyze the variation in the number of an organization participating, b) identify the variation in the type of funding, c) verify the existence of a relationship between the performance and the longevity of the organization, $d$ ) verify the existence of a relationship between the performance and the type of funding. Methods: The research was designed as an exploratory case study. A total of 86 organizations took part in the league during the period, with 767 different teams playing competitions between U-11 and senior. Results: Instability is the main characteristic of the league. The organizations competing are constantly changing the type of funding and unable to stay in the league for long periods. The research also showed that there is a relation between a stable source of funding and performance. Conclusion: Instability is the main problem in Brazilian youth and amateur basketball organizations. This study presents useful information for managers better understand the problems and difficulties of basketball in Brazil.
\end{abstract}

Keywords: sport funding, amateur sport, team performance, youth sport, basketball.

\section{Introduction}

Youth sport is a key theme within physical education and sport, involving different areas of knowledge. The importance of youth sport for the physical and mental wellbeing of young people and its influence on adult life is a well-known phenomenon ${ }^{1}$. Furthermore, the investment in youth sport (i.e., soccer), is directed related to positive results in international competitions ${ }^{2}$.

The national sports structure, especially amateur and youth sports, varies from country to country. In the case of youth sports, these structures can be centralized, focused on sports clubs or schools. Regional specificities make it difficult to develop a general analysis or compare two or more sports in different countries ${ }^{2}$, thus, the research usually focuses on individual cases. There is a growing body of studies in sport management focused on the sports structure of various countries; however, these researches are usually done in developed nations. The studies discussing developing nations are scarce, with the few research showing that these nations usually have an underdeveloped sports structure ${ }^{3}$. This group of nations is diverse and faces specific issues that can only be tackled through individual analysis of these nations.

Brazilian sports management research is limited, mostly restricted to federal initiatives ${ }^{4}$. The specific characteristics of the country, territorial extension, and decentralized sports policy limits the use of established methodologies and prevent comparisons with other countries $^{5}$, a problem shared by Latin America in general ${ }^{6}$. In addition, there is a disconnection between the various federal, state, and municipal initiatives, often with conflicting goals and methods.

The development of young athletes is related to access to an adequate competition system. An interesting and structured competition maintains the athletes' motivation while ensuring their physical and technical development ${ }^{7}$. Thus, to better understand how youth competition at the local level is funded and organized this study analyses the profile of the teams participating in a regional competition in São Paulo state over 8 years (2012-2019). Designed, as an exploratory case study, the researchers determined the teams that participated in the entity's tour- 
naments in that period, as well as their funding, with the aim of a) analyze the variation in the number of an organization participating, b) identify the variation in the type of funding, c) verify the existence of a relationship between the performance and the longevity of the organization, d) verify the existence of a relationship between the performance and the type of funding.

\section{The structure of Brazilian sport}

Brazil sports competitions are historically centralized around confederations and federations. The Brazilian Olympic Committee is the maximum sports entity of the country, below are the confederations responsible for the management of each sport at the national level (there are 53 confederations in the BOC), in the case of this article basketball is under the management of the Brazilian Basketball Confederation (CBB in Portuguese).

The federations manage the sport at the state level. In the case of youth sport, most competitions happen at the state level. The territorial extension of Brazil difficult the organization of national youth championships, even at the state level, the situation is complex. Research shows that the financial burden of long trips limits access to youth sport or makes it impossible in some cases ${ }^{8}$.

Despite the political and economic power of federations and confederations, the country does not have a unified sports project as in the case of Norway ${ }^{9}$ or England ${ }^{10}$ or a predominant type of sport organization. For example New Zealand ${ }^{11}$, Canada ${ }^{12}$, and most of Europe ${ }^{13}$ where youth sport is linked to amateur clubs, non-profit organizations run by volunteers. In the Brazilian case, there is no predominant type of organization. The country has a variety of organizations, Non-governmental organizations, municipalities, schools, amateur clubs, non-profit associations that mix in various competitions.

In this diverse environment, the first contact with competitive sports usually occurs at amateur clubs or in initiates promoted by municipalities, often having the work guided by a deliberate practice in a single sport ${ }^{14}$. The clubs are expensive, so the membership is restricted to the upper classes. Ideally, the municipality should be the main promoter of youth sport, however, the efficiency of these initiatives depends on the region's socio-economic development and is subject to political interests ${ }^{15}$. The existence of thousands of municipalities, each with its policy, the absence of a national database, and the lack of reliable data makes it difficult to conduct a comprehensive survey on municipality sport in Brazil ${ }^{16}$.

Brazilian sport, as part of a global trend, has undergone important transformations in the last decades. The advancement of the neoliberal ideology influenced sports policy ${ }^{4}$, with a decrease in the direct public spending and an incentive to private investment. In Brazil, with the 2016 Rio Olympics and 2018 FIFA World Cup, the public spending in sport had a sharp increase followed by a steep decline afterwards ${ }^{17}$; the consequences of this process are still not fully understood.

The main transformation in Brazilian sports institutions took place in 1998, with the promulgation of the Pelé Law $^{18}$. Created with a focus on regulating labor relations in football, it brought a series of important changes to the sport in general, being the first law to acknowledge sports leagues. The Pelé law allows clubs to organize and manage their championships apart from the Federation and Confederation. Before that, legally, there was no possibility of a championship outside federated control.

Youth sports have their characteristics and must be thought differently from traditional championships ${ }^{19}$ the leagues allow competitions to be held on a smaller scale than the state, so small clubs from nearby cities can create their regional competition. Another issue is that youth sport is not necessarily focused on performance and must take into account the development and needs of children ${ }^{20}$. The leagues allow clubs to shape competitions according to their necessities by creating an environment that better adapts to their athletes' profile. In the traditional structure, the relationship with the federations is more distant, and given their size, the freedom of clubs to shape competitions is limited.

\section{Basketball in Brazil}

Basketball is one of the most popular sports in Brazil, has a wide base of fans and practitioners, is part of the national school curriculum ${ }^{21}$. The country is also one of the biggest international markets for the NBA (see Internet Resources section). Brazil has a winning record in international competitions, despite some poor results in the last years. The men's team has three Olympic bronze medals and two world championships. The women won a world championship and a silver medal at the Olympic Games. Nationally, basketball is managed by the Brazilian Basketball Confederation (CBB in Portuguese), affiliated to CBB there are 27 state federations, responsible for managing the sport at the state level, all Brazilian states have a basketball federation.

In the case of this article, the teams analyzed are linked to the São Paulo Basketball Federation (FPB). The state of São Paulo is the commercial center of Brazil and the home to the majority of Olympic athletes ${ }^{22}$. The state is also a basketball stronghold, with the largest number of teams, professional and amateur ${ }^{23}$.

As already discussed, the distance is one of the main problems in Brazil youth sport São Paulo is considered a medium-sized state, however, it has an area like the United Kingdom with teams in state competitions often traveling more than 6 hours to play. To facilitate the ac to the sport the FPB divided the state into four independent entities, the Basketball Regional Association (ARB in Portuguese) is one of them, these new organizations manage competitions from U-11 to senior. From U-11 to the U-15 the 
regional championships are classificatory to the state championships, a small part-year tournament. To the categories above 16 years old, the state championship remains a year-round event; the teams may choose to play both, federation and regional, or one of them depending on their rooster size and financial conditions.

It is important to highlight that this is not a long-term project or of the FPB. The regional initiatives appeared spontaneous in the state. The 1998 Pelé Law gave juridical support to the newborn leagues and the FPB eventually realized the potential of these entities and include them in the official state structure. So, this is not an official division of the state and there is no obligation for teams to play in their region. Some parts have a more active basketball scene while others are left behind with teams still having to travel long distances to play.

The ARB was created in 1990 aiming to be a cheaper alternative for the teams of the Campinas region who had no interest in financial conditions to play the state championship. It hosts tournaments ranging from U-11 to senior, female, and male. The ARB was originally imagined as an independent league, but in 2000 it was officially including in the FPB, however, the organization maintains the freedom to organize its competitions. The city of Campinas is located around $130 \mathrm{~km}$ from the capital São Paulo, it is the second-largest city of the state, and the region, with around four million inhabitants, is the countryside mains economic hub.

\section{Methodology}

This study has a longitudinal cut; it analyzed 8 years of sports competitions organized by the Regional Basketball Association (ARB). The data were extracted from the official archive of the entity; therefore, this research is characterized as documentary research whose sources were in the public domain. The researchers extracted data from all competitions between 2012 and 2019, the participating clubs and age groups.

The research also determined the type of funding of the teams which were divided into three categories: a) public: when it was funded only by a public entity; b) private: when the team was funded by a private entity; c) public / private: the joint relationship between the city and a private entity. First, the researchers determined the main funding source by analyzing the organizations' names and the official websites, when the funding source was not clear the researchers contacted the organizations for further information, being able to determine the funding source of all the clubs.

The sports results of each club were calculated based on a ranking created by the team of researchers specifically for this study in which the age group champion team was awarded 4 points; the runner-up had 3 points; the third-placed team had 2 points and the fourth-placed team had 1 point. The ranking was created to differentiate the best-ranked teams in each category and, consequently, give different weights to these teams according to their performance. After, we created three groups of classification: group 1 (organizations with 0 points in the ranking), group 2 (organizations with less than 10 points in the ranking), and group 3 (organizations with 10 or more points in the ranking).

All data were organized in an ad hoc spreadsheet. For the analysis, descriptive statistics were used from the crosstabs command to verify the number of organizations by year and in which age-grade they participated, as well as to verify the eventual modification in the type of funding. Chi-square test with Fisher's exact test was used to determine the existence or not of an association between a) performance and the longevity of each organization the ARB tournaments; b) changing in the type of funding and performance, and c) the exclusivity of public or private funding and the longevity of the organizations.

With these goals, the data was organized into 3 categories: performance (group 1: teams that did not play a minimum semifinal in anyone championship; group 2: teams with 9 or fewer points in the ranking; group 3: teams with 10 or more points in the ranking), the longevity of each organization the ARB tournaments (group 1-2: organizations that played one or two years on ARB tournaments; group 3-6: organizations that played between 3 and 6 years on ARB tournaments; group 7-8: organizations that played between 3 and 6 years on ARB tournaments) type of funding (exclusivity or none of one type of funding).

To calculate the magnitude of association (effect size), we used Cramer's V interpreting by 0.01 to 0.1 as little association, 0.1 to 0.3 as low association, 0.3 to 0.5 as moderate association, and $>0.5$ as high association. We also interpreted the standardized residuals adapted from contingency tables $(>|1.96|)^{24,25}$.

\section{Results and discussion}

\section{The instability in the number of organizations}

Table 1 shows the total number of organizations that participated in ARB championships between 2012 and 2019, and in which age group. A total of 80 different organizations, encompassing NGO, schools, municipalities, and amateur clubs took part in ARB competitions. In total 52 males' and 28 females' organizations played. The data shows an unstable scenario with the organization constantly leaving the competition, there was a peak in participation in 2012 when 58 organizations disputed the league with just 28 in 2016. Only 9 males' and 2 females' organizations played every year, even so, these clubs did not participate in the same age groups. 
Table 1 - Total of teams and organizations by year, gender, and age group.

\begin{tabular}{|c|c|c|c|c|c|c|c|c|c|c|c|c|c|}
\hline & Year & U-11 & U-12 & U-13 & U-14 & U-15 & U-16 & U-17 & U-19 & U-21 & Senior & Teams & Organizations \\
\hline \multirow[t]{9}{*}{ Female } & 2012 & 0 & 4 & 5 & 5 & 0 & 0 & 9 & 0 & 0 & 8 & 31 & 16 \\
\hline & 2013 & 0 & 0 & 5 & 0 & 5 & 0 & 5 & 0 & 0 & 6 & 21 & 10 \\
\hline & 2014 & 0 & 0 & 6 & 0 & 5 & 0 & 6 & 0 & 2 & 5 & 24 & 11 \\
\hline & 2015 & 0 & 0 & 7 & 0 & 8 & 0 & 5 & 0 & 0 & 10 & 30 & 16 \\
\hline & 2016 & 0 & 0 & 0 & 0 & 6 & 0 & 0 & 0 & 0 & 6 & 12 & 8 \\
\hline & 2017 & 0 & 0 & 0 & 0 & 0 & 0 & 0 & 0 & 0 & 5 & 5 & 5 \\
\hline & 2018 & 0 & 5 & 3 & 0 & 4 & 0 & 5 & 0 & 0 & 4 & 21 & 10 \\
\hline & 2019 & 4 & 6 & 8 & 0 & 5 & 0 & 0 & 0 & 0 & 0 & 23 & 10 \\
\hline & Total & 4 & 15 & 34 & 5 & 33 & 0 & 30 & 0 & 2 & 44 & 167 & 86 \\
\hline \multirow[t]{9}{*}{ Male } & 2012 & 0 & 12 & 8 & 13 & 17 & 0 & 12 & 4 & 9 & 16 & 91 & 38 \\
\hline & 2013 & 0 & 11 & 15 & 10 & 10 & 0 & 15 & 0 & 7 & 12 & 80 & 33 \\
\hline & 2014 & 0 & 14 & 12 & 12 & 13 & 0 & 13 & 6 & 6 & 12 & 88 & 29 \\
\hline & 2015 & 0 & 12 & 10 & 12 & 17 & 0 & 15 & 0 & 8 & 9 & 83 & 29 \\
\hline & 2016 & 0 & 9 & 10 & 9 & 12 & 0 & 13 & 0 & 5 & 6 & 64 & 25 \\
\hline & 2017 & 0 & 9 & 9 & 12 & 10 & 0 & 13 & 0 & 4 & 6 & 63 & 23 \\
\hline & 2018 & 0 & 11 & 10 & 11 & 11 & 0 & 11 & 3 & 0 & 5 & 62 & 24 \\
\hline & 2019 & 6 & 8 & 10 & 8 & 9 & 12 & 10 & 0 & 6 & 0 & 69 & 22 \\
\hline & Total & 6 & 86 & 84 & 87 & 99 & 12 & 102 & 13 & 45 & 66 & 600 & 223 \\
\hline \multirow[t]{9}{*}{ Total } & 2012 & 0 & 16 & 13 & 18 & 17 & 0 & 21 & 4 & 9 & 24 & 122 & 54 \\
\hline & 2013 & 0 & 11 & 20 & 10 & 15 & 0 & 20 & 0 & 7 & 18 & 101 & 43 \\
\hline & 2014 & 0 & 14 & 18 & 12 & 18 & 0 & 19 & 6 & 8 & 17 & 112 & 40 \\
\hline & 2015 & 0 & 12 & 17 & 12 & 25 & 0 & 20 & 0 & 8 & 19 & 113 & 45 \\
\hline & 2016 & 0 & 9 & 10 & 9 & 18 & 0 & 13 & 0 & 5 & 12 & 76 & 33 \\
\hline & 2017 & 0 & 9 & 9 & 12 & 10 & 0 & 13 & 0 & 4 & 11 & 68 & 28 \\
\hline & 2018 & 0 & 16 & 13 & 11 & 15 & 0 & 16 & 3 & 0 & 9 & 83 & 34 \\
\hline & 2019 & 10 & 14 & 18 & 8 & 14 & 12 & 10 & 0 & 6 & 0 & 92 & 32 \\
\hline & Total & 10 & 101 & 118 & 92 & 132 & 12 & 132 & 13 & 47 & 110 & 767 & 309 \\
\hline
\end{tabular}

It is possible to note the absence of long-term projects. The predominance of short-term initiatives damages the structure of the organizations and makes it more difficult for long-term goals to be achieved ${ }^{26}$. The research analyzed only the ARB competitions, it is not possible to say if the clubs continued to play outside the league or terminated their activities.

This instability was also present when analyzing the age groups, the organizations did not compete in all possible age groups some played with 5 teams other with just one. There was also no logic in this participation some organizations played in one year in the U-12 and senior and in the next in the U-17. This shows this is also a reflection of the absence of long-term projects with the organizations competing each year with the players available at the moment. They are unable to create a structured environment where, as they grow old, the players change age groups. No analyzed organization was able to compete every year in every age group.

This situation was more evident in the case of females, where the competition was concentrated in the U-
13 , U-15, and U-17 age groups. Possible due to the lack of athletes the organizations decided to merge different age groups to make the championship feasible, nonetheless the number of female clubs is limited in each age group. The instability is problematic to organizations and players. Competing below the recommended age group impairs the development of the athlete, as they play against weaker smaller opponents while against older players, they have a higher risk of injury.

The smaller female participation, when compared with the male, was already expected. The gender imbalance in sports participation is a well-discussed phenomenon in the literature ${ }^{27,28}$. The Brazilian women's basketball achieved its greatest feat in 1996, the Atlanta Olympic Games silver medal, however, the sport could not capitalize on the good moment. Misguided strategies and wrong investments lead to a crisis in the sport with poor international results and a declining number of players ${ }^{29}$.

The data analysis shows the weakness of this category in the region. The goal of the regionalization was to reduce the distances and facilitate the practice; however, 
this does not seem to have contributed to an increase in the number of clubs and players. An especially worrying scenario considering that the interior of the state of São Paulo is traditionally the largest producer of female basketball athletes ${ }^{30}$.

There was also a constant decline in overall participation as the player's age. The issue of sports participation is a hotly debated topic within physical education and sports management. Participation is related to socioeconomic, demographic, cultural, and regional factors ${ }^{31}$. In the case of age, there is no consensus in the literature with studies showing a steady decline in participation during time ${ }^{32}$ while others describe this phenomenon in a format closer to a $\mathrm{U}$, with a return to sport in older $\operatorname{ages}^{33}$. In the Brazilian case, the possibility of return is small.

The data collected seem to support the idea of a pyramidal structure on youth sport, as exposed in Graph 1. In the female category, there is a decrease of $22.4 \%$ between U-13 and U-15, 21.0\% between U-15 and U17, and 93.3\% between U-17 and U-21, indicating the almost nonexistence of teams in this category. In the males, the number of teams in the U-15 is $9.4 \%$ higher than the teams in the U-13, demonstrating a possibility of later entry into the modality in that category. There is also a reduction of $38.7 \%$ in teams between $\mathrm{U}-15$ and $\mathrm{U}-17$ and $50.9 \%$ between U-17 and U-19.

The overall number of organizations is reduced by half between the U-17 and U-21 (Figure 1). This decrease shows the difficulty in maintaining athletes beyond school age, a well-discussed phenomenon ${ }^{34}$. In the case of this research, it is important to highlight the fact that most of the clubs are in small cities, and many of the students after finishing high school move to bigger cities. In the older age groups is possible to notice a concentration in the senior category. Like what happened in the female, the organizations, instead of playing different age groups concentrated all above 18 athletes in one age group, to produce a more competitive championship.

Given the longevity of data collection is natural that changes would occur during the period. In this case, there was the appearance of the circuits. In 2017 the female organizations broke with the ARB, not competing in any youth category (Table 1), these teams opted to compete in what was called "circuit". The season consisted of several stages of a one-day competition; all organizations traveled to one city were played several short games. Also, the organizations decided that there would be no champion.

The circuits pleased the teams due to the reduced cost, with one trip is possible to face several adversaries. The youth female clubs returned to ARB in 2018, which adopted the circuits in the female U-12 and U-23 categories. In 2019 this model was expanded to the female U$11,12,13$, and 15 and the newly created males U-11 and U-16 categories.
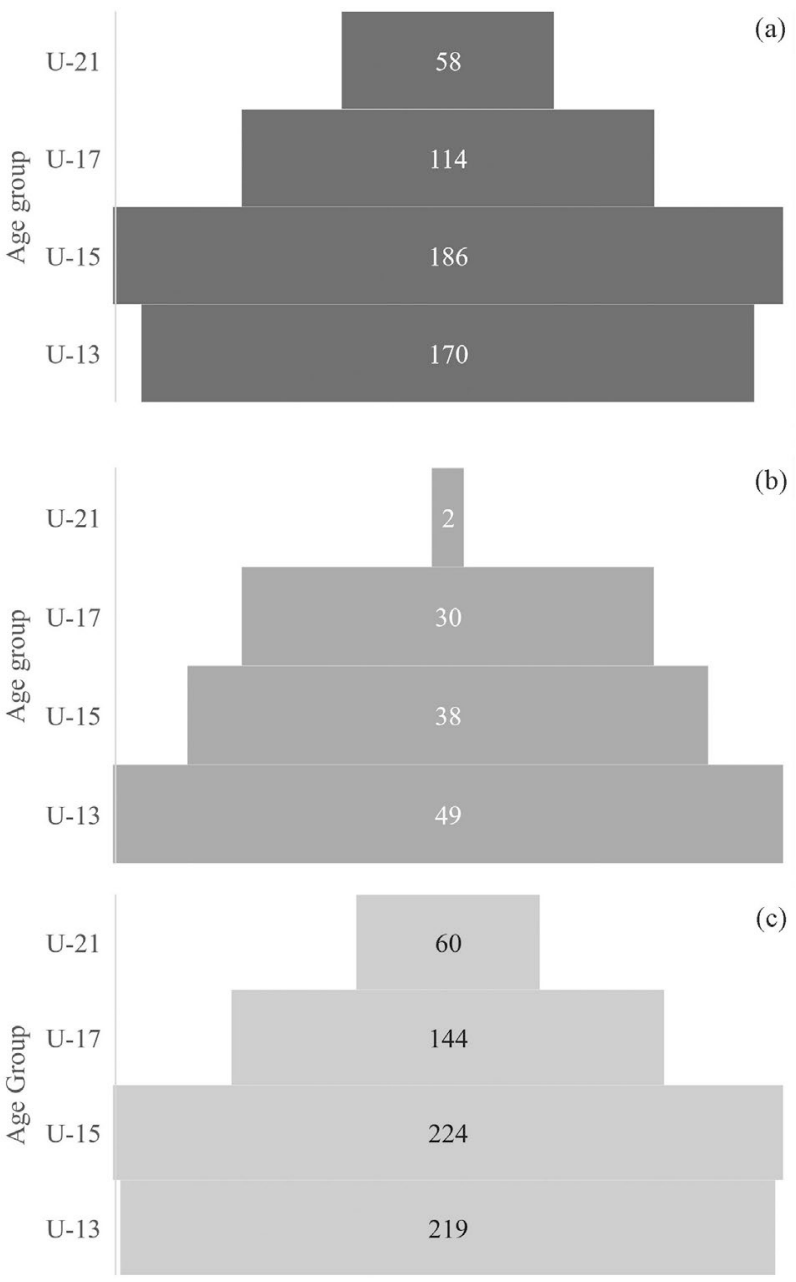

Figure 1 - Pyramidal distribution of teams by age group between 2012 and 2019 (a) male, (b) female, (c) total.

Youth sport requires a series of adaptations to ensure the complete development of athletes. In this sense, circuits are a tool recommended by the literature, reducing distances, and improving the athletes' experience ${ }^{35}$. The process of creating the circuits also shows one of the objectives of creating regional entities, the easiness of the teams to shape the championship according to their needs.

\section{The funding}

The organizations were divided into three funding categories, public, private, and public-private partnership. The instability detected in the number of organizations participating is also present in funding, when analyzing the organizations that played more than one season (of 80 organizations, 10 males and 10 females played just one season). The participation over time in the league seems to be related to the management's capability to find new sources of income (Figure 2). The organizations that participated between 2 and 3 years had a more stable source of funding, 17 (80.9\% of them) did not change their type of funding, while $4(19.0 \%)$ changed. While the organiza- 


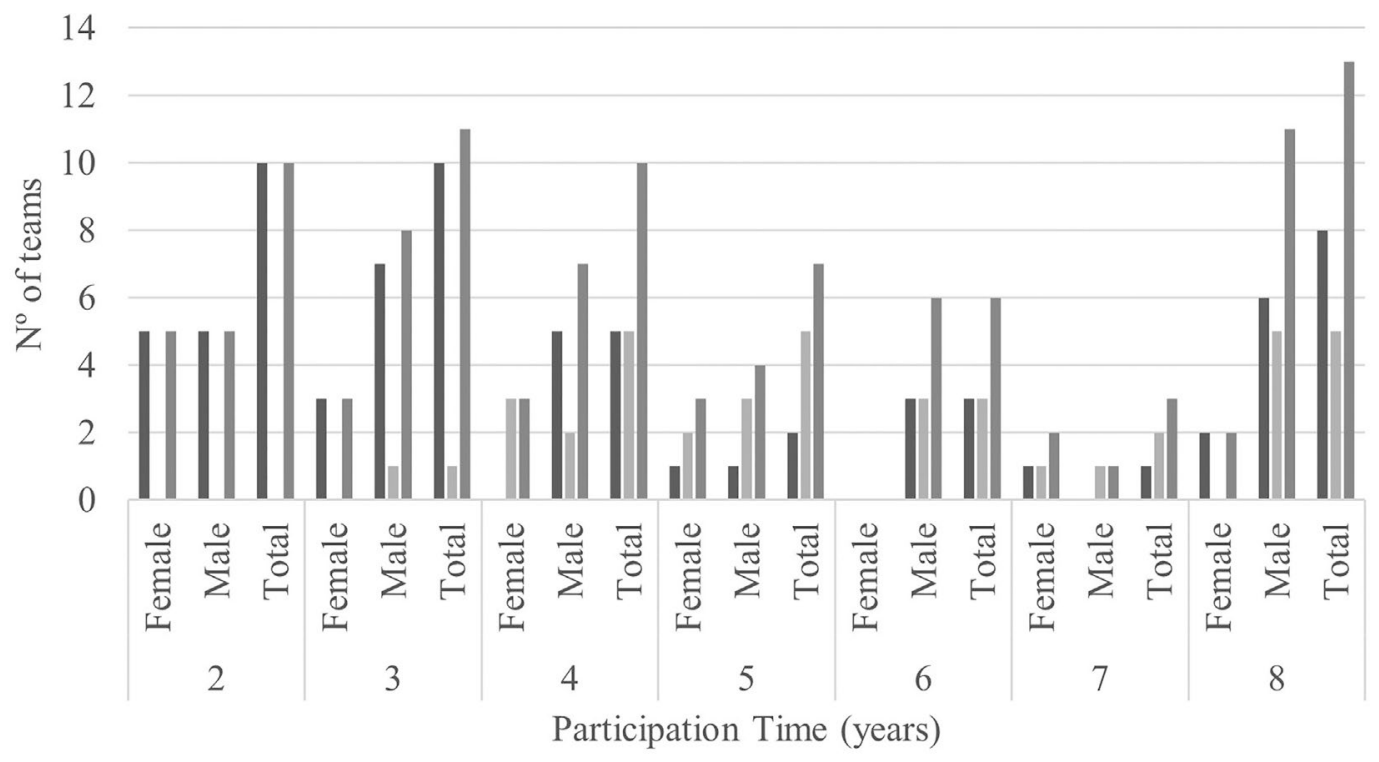

- No changes of financial support $\square$ Changes of financial support $\square$ Total

Figure 2 - Changes in the type of funding in the ARB organizations between 2012 and 2019.

tions that played between 4 and 6 years, $15(46.9 \%$ of them) did not change their type of funding, and 17 (53.1\%) had changed. However, the nine teams that played in all seasons did not change the type of funding.

As an exploratory study is possible to speculate that change in the type of funding can keep the organization in the league, however, this situation has limits. And to have a long-term project the organizations need a stable source of income.

The leagues' instability seems to be related to the organizations difficulties to find a steady source of funding. The managers are constantly seeking new types of funding transitioning between public and private money, and when they fail the organizations drop out of the competition. This contributes to an unstable scenario that is prejudicial to players and organizations. The instability is part of both categories, nonetheless, the research showed differences between the way female and male basketball is funded.

Male basketball is mostly privately funded, with $40.4 \%$ of the entities that participated in the eight seasons having this type of funding, $38.4 \%$ are public and $19.2 \%$ are public/private. The organizations that played between 1 and 4 years were mostly public. The difficulties related to public investment in sport are not exclusive to Bra$\mathrm{zil}^{26,36}$, with studies criticizing the way government invests in sport ${ }^{37}$. In this sense, this research seems to corroborate, even if is not conclusive, some of these criticisms showing that public organizations tend to be shortterm projects contributing to the general instability of competitions. Also contributing to this view is the fact that of the 9 organizations that participated in the eight seasons analyzed 5 were privately funded, with no public team playing all seasons. The other 4 became public-private partnerships at one point or another.

This category also presents an interesting phenomenon. Even with the limited time frame is possible to see a change in the profile of the organizations. In 2012, 47.4\% (18 in a total of 38 ) of the teams were funded exclusively by the government while in 2019, the proportion decreased to $30.4 \%$ ( 7 in a total of 23 ). From the limited sample, it is not possible to define a standard behavior for investments, but other studies point out that there is a tendency towards a decrease in state investment in sport or a change in the way the public authorities make this investment $^{38}$. In the Brazilian case, the result also relates to the decrease in the public investment in the sport after the 2016 Olympic Games.

One of the new ways for the state to encourage sport is through public-private partnerships or by encouraging private investment. This process, however, is not direct, being subject to a series of difficulties, which may explain the general decrease in the number of teams, as state initiatives are reduced and are not replaced by private projects ${ }^{39}$. In the case of the ARB, the public-private partnerships have been erratic, after a peak in 2017, when 6 out of 22 organizations had this type of funding there were no public-private partnerships in 2018 and 2019.

The female category presented a different picture, being mostly financed by public money. In the 8 -years analyzed $64.3 \%$ of the organization that competed were publicly funded, $10.7 \%$ were public-private and $25.0 \%$ private. Public funding is central to the category, private investment is restricted and often connected with public 
Table 2 - Crosstabulation, statistics test, and standardized residuals considering the association between overall performance and (a) the number of years participating in the ARB tournaments, and (b) changing in the type of funding, for all sample $(n=80)$.

\begin{tabular}{|c|c|c|c|c|c|c|c|c|c|c|c|}
\hline & \multicolumn{4}{|c|}{ Performance group } & \multicolumn{4}{|c|}{ Statistics test } & \multicolumn{3}{|c|}{ Standardized residual } \\
\hline & G1 n (\%) & G2 n (\%) & G3 n (\%) & Total & $\chi^{2}$ & df & $\mathbf{p}$ & Effect size ${ }^{*}$ & G1 & G2 & G3 \\
\hline \multicolumn{12}{|c|}{ Years in tournament } \\
\hline G $1-2$ & $27(90.0)$ & $2(6.7)$ & $1(3.3)$ & 30 & & & & & 6.1 & -3.7 & -3.2 \\
\hline G 3-6 & $10(29.4)$ & $20(58.8)$ & $4(11.8)$ & 34 & 67.958 & 4 & 0.000 & 0.652 & -2.6 & 4.6 & -2.0 \\
\hline G 7-8 & $0(0.0)$ & $3(18.7)$ & $13(81.3)$ & 16 & & & & & -4.1 & -1.2 & 6.3 \\
\hline \multicolumn{12}{|c|}{ Changing in the type of funding } \\
\hline No & $33(55.9)$ & $15(25.4)$ & $11(18.6)$ & 59 & 8.482 & 2 & 0.013 & 0.326 & 2.9 & -1.9 & -1.4 \\
\hline Yes & $4(19.0)$ & $10(47.6)$ & $7(33.3)$ & 21 & & & & & -2.9 & 1.9 & 1.4 \\
\hline
\end{tabular}

investment. Only one organization has been able to play two years in a row with private funds, the others had to resort to public-private partnerships to keep playing.

It is not possible to discuss the variation in the type of funding in the female category. It is almost completely publicly funded and the number organization playing the ARB seem linked with the availability of publicly funded initiatives in the regions when it grows there are more teams when it decreases the basketball also decrease.

In brief, the female category is dependent on public funding while the male presents a more diverse environment. Gender inequality in sport is a serious problem with women having limited opportunities to engage in sports practice $^{40}$. This research also confirms the lack of private interest in girls sport, traditionally basketball in Brazil is linked with private clubs, but these organizations seem to have little interest in the female category ${ }^{41}$. So, the only institution interested in female basketball is the state, a concerning scenario.

\section{Sports results}

Regarding sports results, considering the teams that finished first to fourth in their respective age group competitions, there is a significant association with a very strong effect in the chi-square tests between the overall performance and the number of years participating in the ARB tournaments, as well a significant association with moderate effect between the overall performance of each sporting entity and changes in funding type (see Table 2).
However, by observing the standardized residuals, is possible to see that the time of participation has a greater contribution to the sporting result than the change in funding.

These results are also confirmed when looking at the percentage of the organization that reached the top four in any of the tournaments (Table 3). In total, $44.1 \%$ of the teams that did not change the type of funding managed to arrive with at least one of their teams among the first four placed in at least one championship, while $80.9 \%$ of the teams that changed the type of funding achieved a similar feat. The teams that did not change the type of funding achieved $40.4 \%$ of the possible results, according to the ranking created for this study, and $59.6 \%$ of the points were achieved by the teams that changed the type of financing.

It is possible to observe an association with a moderate effect between an exclusive source of investment, public or private, and the longevity of ARB tournaments for the total sample, especially to groups until six years of participation in tournament (Table 4). However, it was not possible to observe an association between exclusively public or private investment and the result of the sport (Table 4). These results indicate that the exclusivity of public or private investment was essential for maintaining the project, but not for obtaining sporting results for the organizations in both categories.

The data are not conclusive, but as an exploratory study, it is possible to discuss some trends. Thus, it is possible to say that a stable source of funding is important for

Table 3 - Scores in the rank created to this research divided by gender and changes in the type of funding.

\begin{tabular}{|c|c|c|c|c|c|}
\hline Gender & Change in the type of funding & Organizations & Organization that scored & Points won & Possible points \\
\hline \multirow[t]{2}{*}{ Female $(n=28)$} & Yes & 22 & 9 & 100 & 183 \\
\hline & No & 6 & 6 & 83 & \\
\hline \multirow[t]{2}{*}{ Male $(\mathrm{n}=52)$} & Yes & 37 & 17 & 311 & 507 \\
\hline & No & 15 & 11 & 196 & \\
\hline \multirow[t]{2}{*}{ Total $(\mathrm{n}=80)$} & Yes & 59 & 26 & 411 & 690 \\
\hline & No & 21 & 17 & 279 & \\
\hline
\end{tabular}


Table 4 - Crosstabulation, statistics test, and standardized residuals considering the association between exclusive source of investment and (a) number of years participating in the ARB tournaments, and (b) performance for all sample $(\mathrm{n}=80)$.

\begin{tabular}{|c|c|c|c|c|c|c|c|c|c|}
\hline & \multicolumn{3}{|c|}{ Exclusivity of public or private investment } & \multicolumn{4}{|c|}{ Statistics test } & \multicolumn{2}{|c|}{ Standardized residual } \\
\hline & No n $(\%)$ & Yes n (\%) & Total & $\chi^{2}$ & df & $\mathbf{p}$ & Effect size & No & Yes \\
\hline \multicolumn{10}{|c|}{ Years in tournament } \\
\hline G $1-2$ & $0(0.0)$ & $30(100.0)$ & 30 & & & & & -3.2 & 3.2 \\
\hline G 3-6 & $11(41.2)$ & $23(58.8)$ & 34 & 15.948 & 2 & 0.000 & $0.463^{* *}$ & 3.0 & -3.0 \\
\hline G 7-8 & $3(43.8)$ & $13(56.3)$ & 16 & & & & & 0.1 & -0.1 \\
\hline \multicolumn{10}{|c|}{ Performance group } \\
\hline G1 & $4(10.8)$ & $33(89.2)$ & 37 & & & & & -1.5 & 1.5 \\
\hline G2 & $6(24.0)$ & $19(76.0)$ & 25 & 2.225 & 2 & 0.329 & 0.164 & 1.0 & -1.0 \\
\hline G3 & $4(22.2)$ & $14(77.8)$ & 18 & & & & & 0.6 & -0.6 \\
\hline
\end{tabular}

the team's longevity and influences positive results. Despite this, teams that do not have a stable source of funding and can remain in the competition through alternative sources of revenue also present positive results, even if inferior to those that are more stable.

\section{Conclusion}

This article analyzes the funding and performance of the teams that participated in ARB competitions during eight seasons. Given the lack of an established bibliography about Brazil, this study aims to initiate the discussion by providing subsidies for future research as well as insights that may contribute to sport management in Brazil and other developing nations.

The instability is the great characteristic of the ARB competition, both categories play in a constantly changing environment dominated by short-term projects. Even in a limited time frame, 8 -years, the organizations were unable to compete in all seasons participating only a few years, or one year. Part of this situation occurs due to funding difficulties, if the organizations want to stay in the competition they must be constantly looking for new sources of funding, transitioning between public, private, and public-private partnerships. In the case of the male category, this apparent instability is related, to a greater degree, to the instability of public initiatives, although more research on this topic is needed to confirm this hypothesis.

The predominance of short-term initiatives causes a series of problems that hinder the technical development of the athletes and the institutional development of the teams. This is corroborated in part by the analysis of the performance of the organizations with the entities that presented a stable source of funding, public or private, having better sportive results.

The research points to the instability of Brazilian youth teams but has not defined their causes. More research is needed to understand the roots of this instability and the best way for managers to deal with this situa- tion. Another important issue presented in the research is the disparity in the funding of male and female teams, showing the private disinterest in the practice of female basketball, almost entirely supported by public investment. This lack of interest is detrimental to the female sport, having roots in the different ways boys and girls are socialized and introduced to the sport. In this sense, more research on this aspect and ways to reduce these disparities are important and incentivize private interest.

The methodology adopted by this article is not the most usual, and we recognize the limitations of the sample. The lack of reliable data on the funding of sports organizations in Brazil, both private and public ${ }^{31,38}$, and the specific characteristics of the Brazilian system make it difficult to apply established methodologies. Thus, this research chose to carry out an innovative approach a methodology that may prove interesting for more comprehensive research in the future, as well as in countries with characteristics like Brazil.

\section{Acknowledgments}

D.M.G. and P.S.N. was supported by the Coordenação de Aperfeiçoamento de Pessoal de Nível Superior [PhD grants].

\section{References}

1. Bailey R. Physical Education and Sport in Schools: A Review of Benefits and Outcomes. J Sch Health. 2006;76:397-401. DOI: https://doi.org/10.1111/j.17461561.2006.00132.x

2. Valentini M, Scelles N, Morrow S. Elite sport policies and international sporting success: a panel data analysis of European women's national football team performance. Eur Sport Manag Q. 2020;20(3):300-20. DOI: https://doi.org/ 10.1080/16184742.2019.1606264

3. Andreff $\mathrm{W}$. The correlation between economic underdevelopment and sport. Eur Sport Manag Q. 2001(4);1:25179. DOI: https://doi.org/10.1080/16184740108721902 
4. Matias WB, Athayde PF, Húngaro EM, Mascarenhas F. A lei de incentivo fiscal e o (não) direito ao esporte no Brasil. Movimento. 2015(1);21:95-110. DOI: https://doi.org/ $10.22456 / 1982-8918.46419$

5. Taylor P. Comparative Sport Development: systems, participation, and public policy. Manag Sport Leis. 2015; 20 (6):313-4.

6. Nicholson M, Hoye R, Houlihan B. Participation in sport: International policy perspectives. Routledge, 2010.

7. Fraser-Thomas, J, Côté J. Understanding adolescents' positive and negative developmental experiences in sport. Sport Psychol. 2009;23(1):3-23. DOI: https://doi.org/10.1123/ tsp.23.1.3

8. Côté J, Hancock DJ. Evidence-based policies for youth sport programmes. Int. Sport Policy Polit. 2016;8(1):51-65. DOI: https://doi.org/10.1080/19406940.2014.919338

9. Strittmatter A.-M, Skille EÅ. Boosting youth sport? Implementation of Norwegian youth sport policy through the 2016 Lillehammer Winter Youth Olympic Games. Sport Soc. 2017;20(1):144-160. DOI: https://doi.org/10.1080/ 17430437.2015.1124568

10. Harris S, Houlihan B. Competition or coalition? Evaluating the attitudes of national governing bodies of sport and county sport partnerships towards school sport partnerships. Int. J. Sport Policy Polit. 2016;8(1):151-71. DOI: https:// doi.org/10.1080/19406940.2015.1024708

11. Bradbury T, Mitchell R, Thorn, K. Moving forward: business model solutions for amateur sport clubs. Manag. Sport Leis. 2020:1-17. https://doi.org/10.1080/ 23750472.2020.1734479

12. Papadimitriou D. Amateur structures and their effect on performance: the case of Greek voluntary sports clubs. Manag. Leis. 2002;7(4):205-19. DOI: https://doi.org/ 10.1080/1360671021000056570

13. Barget E, Chavinier-Rela S. The analysis of amateur sports clubs funding: a European perspective. Athens J Sport. 2017;4(1):7-34.

14. Ericsson KA, Krampe RT, Tesch-Römer C. The role of deliberate practice in the acquisition of expert performance. Psychol Rev. 1993;100(3): 363-406.

15. Barros CP, Lucas J. Sports managers, and subsidies. Eur. Sport Manag. Q. 2001;1(2):112-23. DOI: https://doi.org/ $10.1080 / 16184740108721891$

16. Corrêia JCA. O setor privado sem fins lucrativos e as políticas públicas de esporte e lazer (2008-2011). Campinas [Mestrado em Educação Física] - Universidade Estadual de Campinas, 2012.

17. Galatti LR. AFEs, Desenvolvimento Humano e Esporte de Alto Rendimento. Programa das Nações Unidas para Desenvolv. 2017; 1.

18. Hirata E, Junior MAF. Bastidores do jogo: as interferências na elaboração da lei Pelé. Proj. História Rev. do Programa Estud. Pós-Graduados História. 2014;49:119-55.

19. Choi HS, Johnson B, Kim YK. Children's development through sports competition: Derivative, adjustive, generative, and maladaptive approaches. Quest. 2014;66 (2):191-202. DOI: https://doi.org/10.1080/ 00336297.2013 .861757

20. Leonardo L, Scaglia AJ. A avaliação de competições esportivas de jovens: definição de categorias e aplicações ao han- debol. Movimento. 2018;24(3):875-88. DOI: https://doi.org/ $10.22456 / 1982-8918.83620$

21. Brazil. Base Nacional Comum Curricular. (Ministério da Educação, 2018). Avaliable from: http://basenacionalco mum.mec.gov.br/ [Accessed 22nd January 2021]

22. Tozetto AVB, Galatti LR, Scaglia AJ, Duarte T, Milistetd M. Football coaches' development in Brazil: a focus on the content of learning. Motriz: J Physical Educ. 2017;23(2): e101712. DOI: https://doi.org/10.1590/s19806574201700030017

23. Cunha LD, Fraiha ALG, Darido SC, Pérez BL, Galatti LR. Career of basketball players in the new basketball of Brazil. Cuad. Psicol. del Deport. 2017(3);17:119-27.

24. Crewson P. Applied Statistics - Desktop Reference. Communications of the ACM vol. 1 (2014).

25. Espírito Santo H., Daniel F. Calcular e apresentar tamanhos do efeito em trabalhos científicos (2): Guia para reportar a força das relações. Rev. Port. Investig. Comport. e Soc. 2017;3:53-64.

26. Girginov V, Toohey K, Willem A. Creating and leveraging knowledge to promote sport participation: the role of public governing bodies of sport. Eur Sport Manag. Q. 2015;15:555-78.

27. Lera-López F, Rapún-Gárate M. Sports participation versus consumer expenditure on sport: different determinants and strategies in sports management. Eur Sport Manag Q. 2005;5(2):167-86. DOI: https://doi.org/10.1080/ 16184740500188656

28. Downward P, Riordan J. Social interactions and the demand for sport: An economic analysis. Contemp Econ Policy. 2007;25(4):518-37. DOI: https://doi.org/10.1111/j.14657287.2007.00071.x

29. Antonelli M, Galatti LR., Machado GV, Paes RR. Pedagogia do esporte e basquetebol: considerações para a elaboração de programa esportivo a partir do clube divino Salvador. Conexões. 2012;10(2):49-65. DOI: https://doi. org/10.20396/conex.v10i2.8637674

30. Beneli LM. Trajetória esportiva de atletas de alto rendimento no basquetebol masculino e feminino no Brasil: estudo retrospectivo. Campinas [Doutorado em Educação Física] - Universidade Estadual de Campinas, 2018.

31. Borges CNF, Tonini GT. Incentivo para el deporte de alto rendimento como política pública: influencias recíprocas entre la ciudad y el deporte. Rev Bras Ciências do Esporte 2012;34(2):281-96. DOI: http://dx.doi.org/10.1590/S010132892012000200003.

32. Eberth B, Smith MD. Modelling the participation decision and duration of sporting activity in Scotland. Econ Model. 2010;27(4):822-34. DOI: https://doi.org/10.1016/j.econ $\bmod .2009 .10 .003$

33. García J, Lera-López F, Suárez MJ. Estimation of a structural model of the determinants of the time spent on physical activity and sport: Evidence for Spain. J Sports Econom. 2011;12(5):515-37. DOI: https://doi.org/10.1177/ 1527002510387080

34. Ruseski JE, Humphreys BR, Hallmann K, Breuer C. Family structure, time constraints, and sport participation. Eur Rev Aging Phys Act. 2011;8(1):57-66. DOI: https://doi.org/ 10.1007/s11556-011-0084-y 
35. Wiersma L. Conceptualization and development of the sources of enjoyment in youth sport questionnaire. Measur Phys Educ Exerc Sci. 2001;5(3):153-77. DOI: https://doi. org/10.1207/S15327841MPEE0503_3

36. Sam MP. The public management of sport: Wicked problems, challenges, and dilemmas. Public Manag Rev. 2009;11(4):499-514. DOI: https://doi.org/10.1080/ 14719030902989565

37. Houlihan B, Green M. Modernization and sport: The reform of Sport England and UK Sport Public Adm. 2009;87 (3):678-98. DOI: https://doi.org/10.1111/j.14679299.2008.01733.x

38. Correia JCA. O financiamento público do $3^{\circ}$ setor nas políticas públicas de esporte e lazer. Rev Bras Ciências do Esporte. 2014;36(2), S667-81.

39. Jones GJ, Edwards MB, Bocarro JN, Bunds KS, Smith JW. A structural perspective of cross-sector partnerships involving youth sport nonprofit organizations. Eur Sport Manag Q. 2018;18(2):133-55. DOI: https://doi.org/10.1080/ 16184742.2017 .1322625

40. Goellner SV. Body, eugenics, and nationalism: women in the first sport and physical education journal published in Brazil (1932-1945). Int J Hist Sport. 2014;31(10):1278-86. DOI: https://doi.org/10.1080/09523367.2013.866552

41. Beneli LM, Galatti LR, Montagner PC. Analysis of socialsportive characteristics of Brazil women's national basket- ball team players. Rev Psychol del Deport. 2017;26(Suppl 1):133-7.

\section{Internet Resources}

https://exame.com/blog/esporte-executivo/head-da-nba-brasil-jae-o-3o-maior-mercado-atras-apenas-de-eua-e-china/

\section{Corresponding author}

Thiago José Leonardi, Universidade Federal do Rio Grande do Sul, Escola de Educação Física, Fisioterapia e Dança, Porto Alegre, RS, Brasil.

E-mail: thiago.leonardi@ufrgs.br.

Manuscript received on January 22, 2021

Manuscript accepted on March 8, 2021

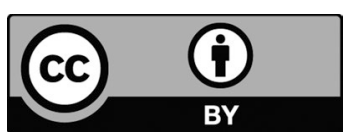

Motriz. The Journal of Physical Education. UNESP. Rio Claro, SP, Brazil - eISSN: 1980-6574 - under a license Creative Commons - Version 4.0 